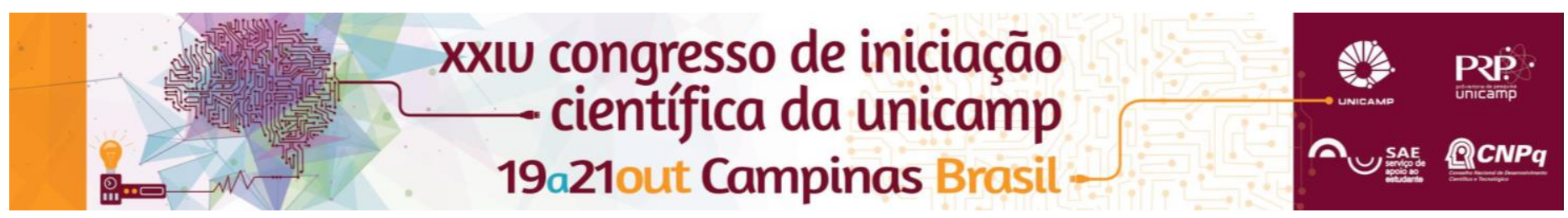

\title{
MAPEAMENTO DA EROSÃO DE MARGENS EM CORPO D’ÁGUA E NA INSTALAÇÃO DO QUEBRA-MAR CONSTRUÍDO DE GARRAFAS PETS.
}

\section{Pamela D. S. Santos*, Tiago Z. Gireli, Luana K. Kelch Vieira.}

\section{Resumo}

Analisando a constante busca por soluções ecologicamente corretas e viáveis, o objetivo principal dessa pesquisa foi o estudo de determinadas regiões para o mapeamento de corpos d'agua que sofrem com a erosão de margem para a utilização do quebra-mar flutuante feito a partir de garrafas PET, que tem como finalidade reduzir as alturas incidentes da onda. A pesquisa tem como base o trabalho de Kelch Vieira (2012) e a partir do mapeamento, o resultado foi a escolha do reservatório de UHE de Ilha Solteira - SP para a projeção do modelo de quebra-mar para aplicação.

\section{Palavras-chave:}

Quebra-mar; Corpos d'água, Mapeamento.

\section{Introdução}

Nesta pesquisa, buscou-se identificar corpos hídricos que sofriam com a erosão de margens. Siqueira e Azevedo (2011) afirmam que a erosão em margens de reservatórios é um tema recentemente estudado no Brasil e em decorrência dos avanços das politicas ambientais do país o estudo dessas regiões tem crescido consideravelmente.

Muitos reservatórios brasileiros utilizados para geração de energia e outras finalidades sofrem o processo de erosão em suas margens $e$ as consequências causadas por ela. Com o mapeamento de diversas regiões, obtemos dados dos reservatórios da UHE de Itaipu, UHE de Porto Primaevera, UHE de Porto Colômbia e da UHE de llha Solteira.

\section{Resultados e Discussão}

O estudo sobre a erosão dessas margens nessas regiões estão avançando, porém, a quantidade de pesquisas em alguns reservatórios ainda é simplória, levando assim a escolha do reservatório de UHE de llha Solteira para a aplicação do quebra-mar de garrafa PET devido a quantidade de pesquisas realizadas na região .

A Figura 1 apresenta o corpo d'agua para dimensionamento do quebra-mar de garrafa PET, para o qual foram reunidos e analisados os dados obtidos por Vieira (2013) e Mattosinho (2015).

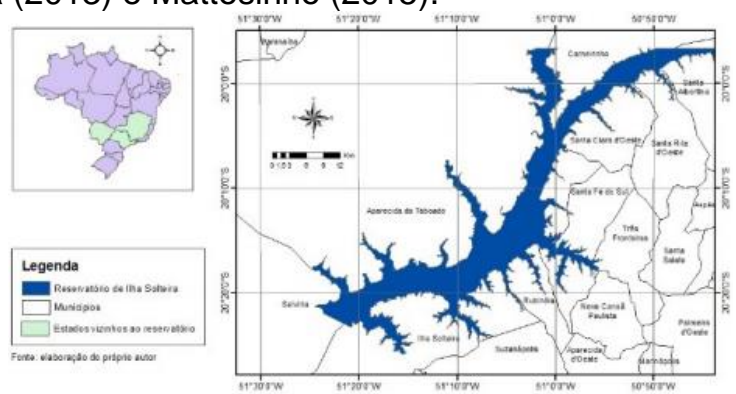

Figura 1. Localização do Reservatório de Ilha Solteira. Fonte: XII Simpósio de Recursos Hidricos do Nordeste.

Com a análise desses dados, foi determinado o local exato da margem para o qual seria projetado o quebra-mar, considerando a intensidade e o rumo do vento direcionado ao ponto, o comprimento da pista de sopro, as alturas máximas de onda no local e a suscetibilidade à erosão do solo. Esta região está delimitada na Figura 2.

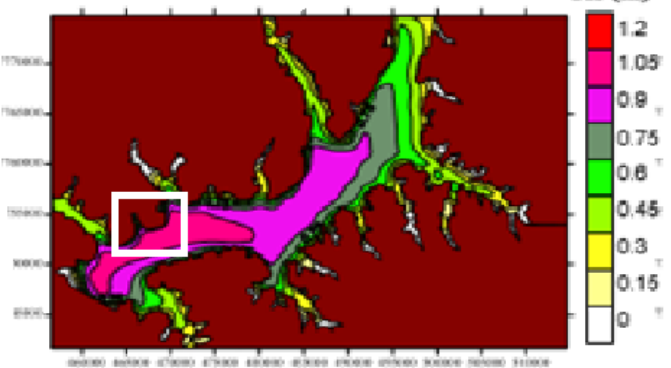

Figura 2. Representação gráfica das alturas significativas de onda (Hs). Fonte: Tese de doutorado de Germano Oliveira (2015)

\section{Conclusões}

Esta pesquisa teve como foco a determinação do local e dos dados deste para o pré-dimensionamento do quebra-mar de garrafa PET.

Ao longo da pesquisa foi desenvolvido também um mecanismo para aplicação do quebra-mar no local devido à variação do nível d'água decorrente da operação do reservatório. O mecanismo seria composto, basicamente, por duas polias, uma fixada ao fundo do reservatório e outra acima do nível (altura o suficiente para proporcionar acesso), sendo controlado manualmente por um funcionário especializado ou por um sistema mecânico que regularia a submergência a partir da tensão nos cabos de ancoragem.

\section{Agradecimentos}

Ao CNPq pela bolsa de iniciação científica, ao orientador Tiago Zenker, à mestranda Luana Kelch, ao mestrando Germano de Oliveira Mattosinho e a doutoranda Adriana Silveira Vieira pela divulgação dos dados.

VIEIRA, L. K. K. Desenvolvimento e Análise de um Quebra-Mar Construído a Partir de Garrafas de Politereftalato de Etileno (PET). São Paulo, Brasil, 2012.

MATTOSINHO,G. O. Comparação entre os softwares Ondiscad e Swan na estimativa de altura signitfactiva de ondas geradas por vento no reservatório da barragem de Ilha Solteira - SP. São Paulo, Brasil, 2015.

VIEIRA, A. S. Analises, Aplicações e Validações - Numérico/Experimentais do Modelo SWAN em Áreas Restritas e ao Largo. São Paulo, Brasil, 2013.

SIQUEIRA, A. G.; AZEVEDO, A.A. Erosão em margens de reservatórios Revista Brasileira de Geologia de Engenharia e Ambiental, São Paulo, n. 89, p. 24, 2011. 